ISSN: $1231-4005$

e-ISSN: 2354-0133

ICID: 1133183

DOI: $10.5604 / 12314005.1133183$

\title{
COST ANALYSIS OF HYDROGEN ENERGY GENERATION
}

\author{
Karol Grab-Rogalinski, Stanislaw Szwaja \\ Czestochowa University of Technology, Institute of Thermal Machinery \\ Armii Krajowej Street 21, 42-200 Czestochowa, Poland \\ tel.: +4834 3250500, +4834 3250524, fax: +48343250555 \\ e-mail: grab@itm.pcz.czest.pl,szwaja@imc.pcz.czest.pl
}

\begin{abstract}
Relatively high energy costs and the perspective of running out fossil fuel natural resources stimulates scientists and engineers all over the world to concentrate their efforts on inventing new sources of energy. For decades, hydrogen technology is considered as source of renewable energy. Hydrogen can be used both as the energy carrier as far as substrate in the chemical industry. Plans for hydrogen utilization as the fuel applied to automotive engines also is under investigation. Lot of works describing various technologies for hydrogen processing have come into being, the ways of production and storing this substance have also been worked out. The important part in analysis is costs of applying fuels with respect to their impact on natural environment. As found, these costs are usually difficult to be estimated. In this paper, the main directions in development of hydrogen technologies were analysed concerning total costs for hydrogen processing. As concluded, overall costs of the technology for both hydrogen generation and electric power production are significantly higher with respect to costs for energy generation by coal-fired power plants. The hydrogen production costs characterized themselves with the highest share in overall costs at hydrogen economy, and they depend on technology development. It is expected that overall costs of production, transportation and storage of hydrogen should be remarkably reduced in short-medium term future because of development in: photovoltaic technology - that will contribute to reduce hydrogen production costs by electrolysis process. Additionally, it is expected to reduce costs for hydrogen storage.
\end{abstract}

Keywords: hydrogen, production, costs analysis

\section{Introduction}

Systematically rising fuel prices and energy deficiency forces developed countries to search for alternative sources of energy for both vehicles and other movable engines as for industrial devices. The development of hydrogen infrastructure, which happened in the recent 20 years shows that change energy carriers into hydrogen, is the political problem rather than the technical one. For the purpose, the US government plans covering 10\% energy demands using hydrogen by 2030 year. Hence, the everlasting question is as follows: Can hydrogen be beneficial in energy generation business? As Bossel [1] answered brilliantly "No" in his final conclusion, no doubts should appear since that time. However, technology of both fuel cells and thermal machinery (internal combustion reciprocating engines, gas turbine engines) is still under systematical improvement. Thus, development in hydrogen to energy conversion is also expected with Hi-Tec in material science as well as combustion engineering. Therefore, review on hydrogen usefulness as fuel is under consideration in minds of politicians, scientists, engineers and businesspersons.

\section{Hydrogen production costs}

Hydrogen is commonly present in nature but mainly as chemical compounds. As the most economically important method of hydrogen are processes, which involve removal of hydrogen from hydrocarbons.

Several technologies for hydrogen production are as follows:

- electrolysis,

- processing of the natural gas (SMR - Steam Methane Reforming), 
- processing of coal (gasification),

- processing of the biogas,

- biological processes (green algae).

In Tab. 1 is shown the percentage share of hydrogen production for commonly used technologies.

Tab. 1. Various sources of hydrogen production [2]

\begin{tabular}{|c|c|c|}
\hline Amount $\left(\times 10^{9} \mathrm{~m}^{3}\right)$ & source & $\%$ \\
\hline 240 & natural gas & 48 \\
\hline 150 & crude oil & 30 \\
\hline 90 & coal & 18 \\
\hline 20 & electrolysis & 4 \\
\hline 500 & Total & 100 \\
\hline
\end{tabular}

The question about the cost of hydrogen does not have a simple answer because it depends on many factors like type of technologies applied, cost of transport and storage and even taxes [3]. It is difficult to express specific costs of hydrogen production with credible accuracy. Several sources give various data. On the basis of references [4-8], the diagram in Fig. 1 presents cost of hydrogen production from various technologies.

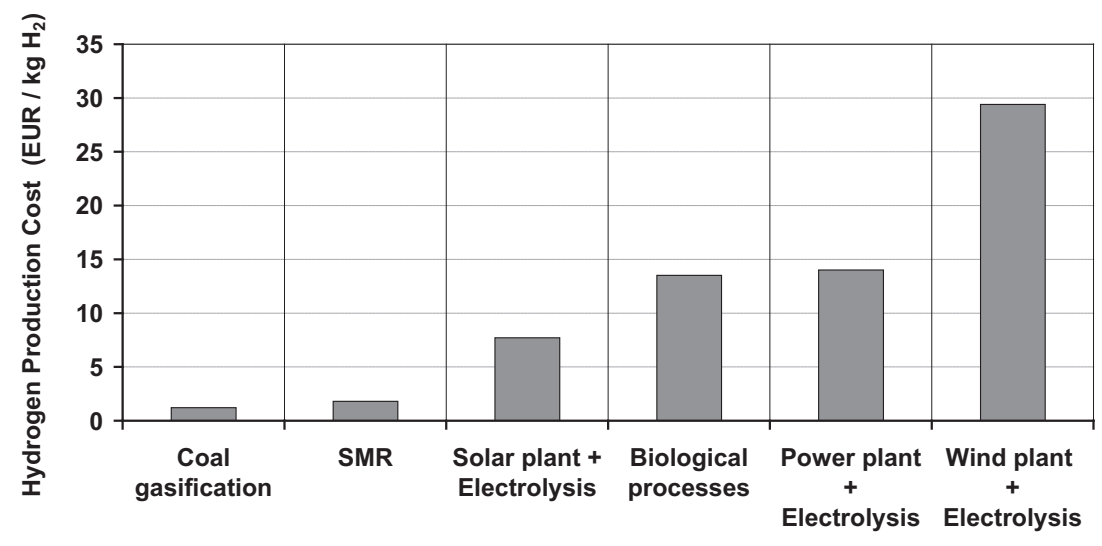

Fig. 1. Costs of hydrogen production from various technologies

According to Fig. 1 the most promising technologies for hydrogen production is steam methane reforming (SMR) and coal gasification. From these technologies, specific cost of hydrogen production (per kilogram) is below $2 €$. As mentioned above, hydrogen infrastructure have also other, additional costs such as storage, delivery, taxes and refuelling stations (for vehicles). Cost of delivery depends on the distance, how far hydrogen will be transported to a destination point. Hydrogen can be delivered to destination point in two phases: gaseous and liquid. Generally, three ways for hydrogen transportation are available as depicted in Tab. 2. As Bossel confirmed [1], the significant cost for pipeline transportation is pumping energy. This energy for hydrogen is much higher than for natural gas; hence, it crucially increases transportation costs through pipelines and stands as the major cons against this transportation method. However, pipelines for gaseous hydrogen feature themselves with the lowest overall transportation costs among the others.

Tab. 2. Hydrogen transportation methods and costs [9]

\begin{tabular}{|l|l|l|}
\hline Hydrogen state & Transportation method & Transportation cost $(\mathrm{EUR} / \mathrm{kg})$ \\
\hline gaseous & pipe line & 1.65 \\
\hline gaseous & tube trailer & 2.16 \\
\hline liquid & tube trailer & 2.09 \\
\hline
\end{tabular}


Another issue as it was mentioned are taxes for hydrogen fuel. In the United States hydrogen which is sold and used as vehicle fuel in liquified state is taxed with $0.5 \$(0.38 €)$ per gallon [10].

\section{Hydrogen to power conversion}

There are several technologies to convert hydrogen to either electric power or mechanical work. Scientists think that hydrogen can be considered as a substance that might replace fossil fuels in long-term future. Nowadays the most favourable methods for hydrogen usage are:

- fuel for a vehicle (internal combustion engine),

- fuel for a fuel cell,

- fuel for an engine in a power generator,

- fuel for a gas turbine.

\section{Hydrogen as fuel for means of transport}

Many research facilities and automotive enterprises are involved in work on hydrogen-fuelled vehicle, e.g. Daimler-Benz, BMW, Ford, Toyota, Honda etc. Advantages and disadvantages of applying hydrogen as the fuel to the internal combustion engine were described in detail by Karim [11]. As commonly known, major drawback of hydrogen when applied to the IC engine is knock $[12,23]$. The knock particularly can be intensified, so be harmful, in case the engine is supercharged $[13,14]$. Hydrogen can be used in a vehicle in two ways as fuel for an internal combustion engine and as energy carrier for a fuel cell, which generates power needed for driven the vehicle. However, in both cases hydrogen have to be stored on board the vehicle.

One of the interesting proposals for reducing cost of exploitation by using hydrogen as fuel to drive a vehicle was given by Polish engineers from Lublin University of Technology [15]. They modified CNG fuel installation to work on hydrogen. As they say, the cost of such installation is about 1520 EUR. However, there is plenty of investigation conducted on the hydrogen-fuelled engine worldwide. Among others, investigation is conducted in the field concerning safety issues, as for the purpose the case hydrogen releases from pipelines [16].

It is easy to calculate that a mid-size passenger vehicle consumes approximately $8 \mathrm{dm}^{3}$ gasoline per distance of 100 kilometres. Considering the average cost of gasoline in UE is 1.4 EUR, it gives 11.2 EUR to drive 100 kilometres on gasoline. In case, the internal combustion engine is fuelled with hydrogen, and keeping the equivalent energy needed to drive 100 kilometres (assuming the same engine efficiency) the overall amount of hydrogen is $27.9 \mathrm{NM}$ which gives approximately $2.24 \mathrm{~kg}$ of $\mathrm{H}_{\mathrm{C}}$. Taking different production costs of hydrogen from various technologies, the cost of driving $100 \mathrm{~km}$ on hydrogen also significantly varies as shown in Fig. 2.

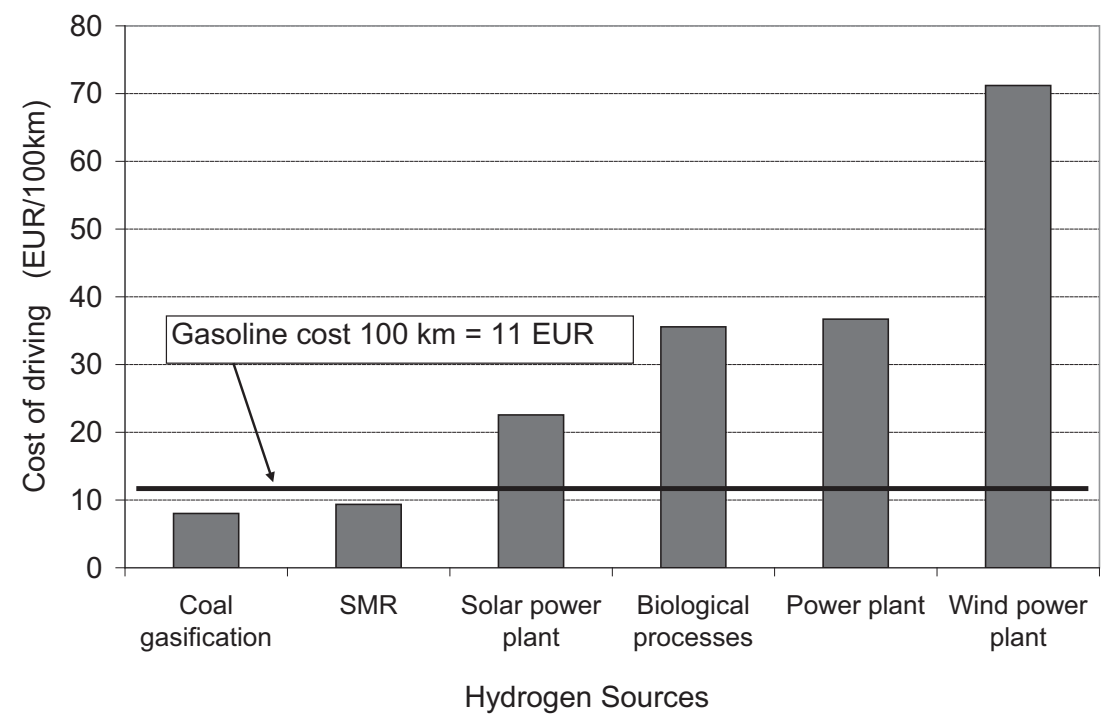

Fig. 2. Comparison between costs of driving $100 \mathrm{~km}$ with gasoline or hydrogen 
Hydrogen fuel cell

Another technique for energy conversion from hydrogen in transport and industry is fuel cell technology, which converts the chemical energy from a fuel into electricity through a chemical reaction. The most common fuel for fuel cells is hydrogen, as oxidizing agent the oxygen is used. The main difference between $\mathrm{H} 2+\mathrm{O} 2$ combustion reaction and $\mathrm{H} 2+\mathrm{O} 2$ reaction in the fuel cell is temperature and reaction rate, which both are significantly lower in the fuel cell.

According to [17] prices of these power generation devices with complete fuel cell systems in the $1 \mathrm{~kW}$ to $3 \mathrm{~kW}$ range are between 3800-22300 EUR. However, the prices for fuel cells have tendency for going down even though prices for precious metals (platinum is a charge to the fuel cell) are systematically going up. To show comparison, estimated costs of production of $1 \mathrm{kWh}$ electric energy using the fuel cell with hydrogen flow rate of $14 \mathrm{dm} 3 / \mathrm{min}$ and power of $1 \mathrm{~kW}$ and average cost of electric energy in EU $0.2 €$ per $1 \mathrm{kWh}$ are presented in Fig. 3 [18]. The price of the hydrogen fuelled fuel cell system is approximately 5200 EUR.

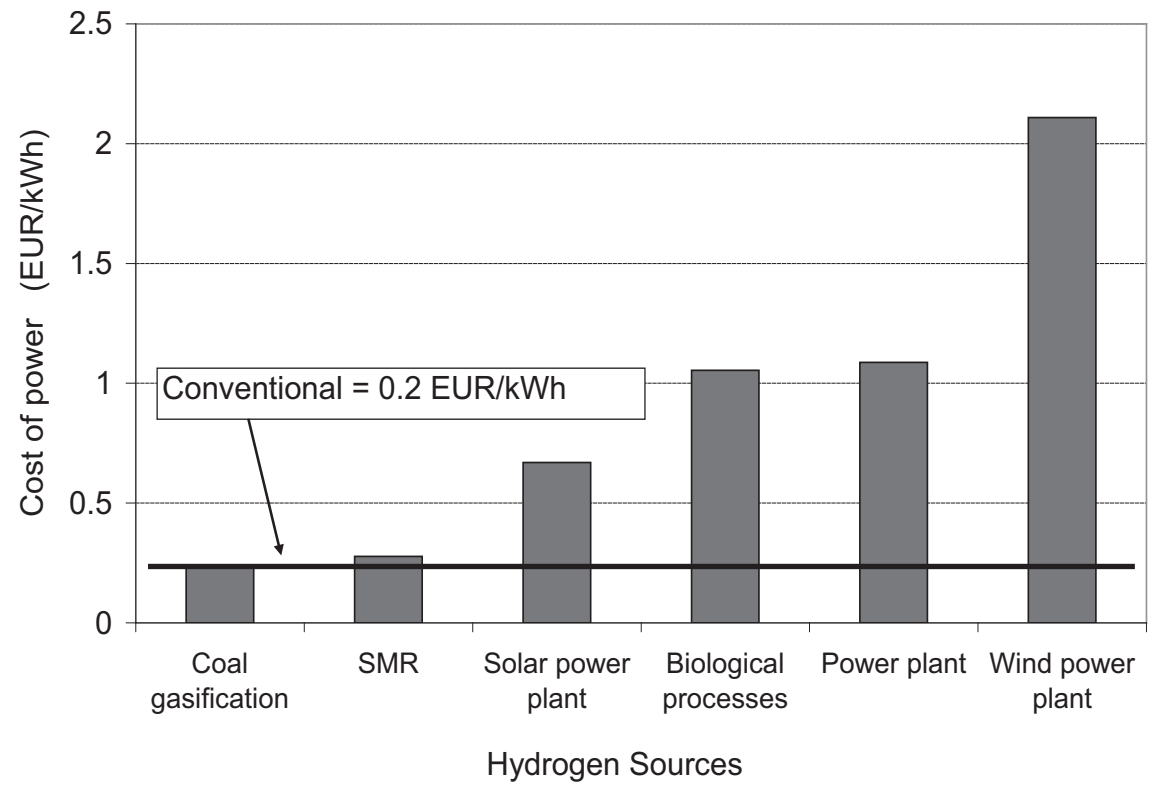

Fig. 3. Comparison of production costs of $1 \mathrm{kWh}$ electric energy from the $1 \mathrm{~kW}$ fuel cell

Hydrogen as fuel for a power generation set

Hydrogen can be also used as fuel to the engine driving the power generators. Currently, power generators are available in a wide range of power output. there are various fuels to supply the power generators. Among others, gasoline, diesel fuel, natural gas and biogas are the most popular as power generators fuels. However, hydrogen can be also applied. As an example, the company Ballard Power Systems in cooperation with Ford Power Products has introduced on the market the first power generator driven by a standard internal combustion engine with swept volume of 6.8 $\mathrm{dm}^{3}$. The so called Ecostar model generates power of $114 \mathrm{kVA}$ with voltage in the range between 120 and $480 \mathrm{~V}$ with frequency of $50 / 60 \mathrm{~Hz}$. Power sources with similar-like power output are delivered to the market by plenty of Asian companies [19].

Comparison between the hydrogen generation set and the classic IC engine driven power generator is presented in Fig. 4. As an example for making comparison the power generator Honda EM5500CXS will be selected. which parameters are: power about $5 \mathrm{~kW}$, the capacity of the fuel tank is 23.51 , time of work is $7 \mathrm{~h} 42 \mathrm{~min}$.

\section{Hydrogen as fuel for a gas turbine}

Projects using the hydrogen technology in the industrial scale were also introduced last years. In the town of Fusina (Italy) in 2010, a power station with a turbine working on hydrogen was built [20]. The construction is able to recover a waste heat from products of combustion in a steam 
boiler. The turbine consumes hydrogen at amounts of of 1.3 tonne per hour and annually produces $6 \times 10^{7} \mathrm{kWh}$ electric energy. As an example, comparison of the costs of production $1 \mathrm{kWh}$ of electrical energy for a gas turbine fuelled separately with natural gas or hydrogen is shown in Fig. 5. Average price of the CNG in Poland is around $0.64 \mathrm{EUR} / \mathrm{m}^{3}$ [21].

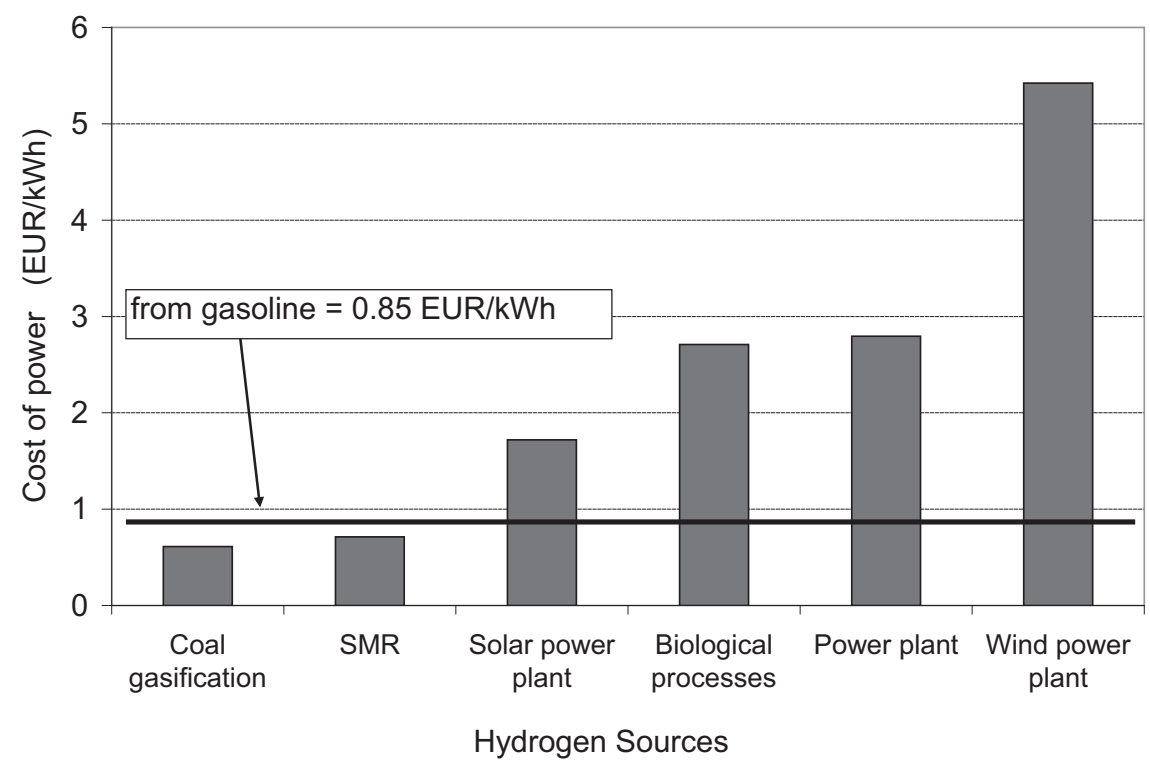

Fig. 4. Cost of production of $1 \mathrm{kWh}$ electrical energy from the power generator

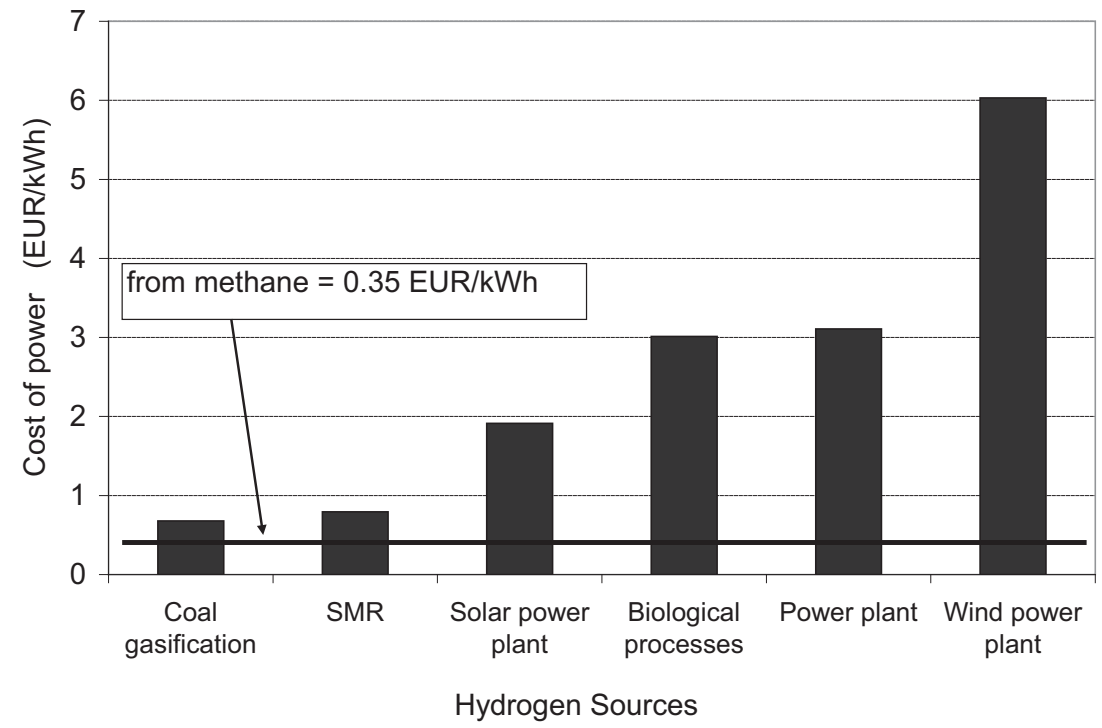

Fig. 5. Cost of $1 \mathrm{kWh}$ produced by a gas turbine

\section{Conclusions}

On the basis of this case study, the conclusions can be formed as follows:

- technologies for hydrogen production using both the SMR and coal gasification are managed as the most profitable with regard to use hydrogen as fuel for means of transport, particularly passenger vehicles, power generators, fuel cells and gas turbines as well,

- applying hydrogen as a fuel for the internal combustion engine can be economically as attractive as gasoline,

- hydrogen as a fuel to the fuel cells for to power generation is not competitive enough when 
compared to power production in conventional way (e.g. coal fired power plants),

- even though hydrogen has heating value by mass higher than that one for natural gas, but applying hydrogen as the fuel to the gas turbine engine is economically unjustified, due to hydrogen high price,

- the technology for hydrogen production characterized itself with the highest share in overall costs at hydrogen economy and it depends on technology development.

Following [22] it is expected that overall costs of production, transportation and storage of hydrogen should be remarkably reduced in short-medium term future because of development in: photovoltaic technology - that will contribute to reduce hydrogen production costs by electrolysis process. Additionally, it is expected to reduce costs for hydrogen storage.

\section{References}

[1] Bossel, U., Does a hydrogen economy make sense?, Journal of KONES, Vol. 11, No. 3-4, pp. 383-394, 2004.

[2] http://www.fuelcelleducation.org/

[3] http://mn.gov/commerce/energy/images/H2ProjectReport2011.pdf

[4] http://www.energy.eu

[5] http://www.nrel.gov/docs/fy04osti/36705.pdf

[6] www1.eere.energy.gov/hydrogenandfuelcells/production/natural_gas.html

[7] www.iea.org/techno/essentials5.pdf

[8] http://www.nrel.gov/docs/fy04osti/35593.pdf

[9] http://www1.eere.energy.gov/hydrogenandfuelcells/wkshp_market_readiness.html

[10] http://www.afdc.energy.gov/laws/law/US/8320

[11] Karim, G. A., Hydrogen as an engine fuel-some pros and cons, Journal of KONES Powertrain and Transport, Vol. 14, No. 4, pp. 153-164, Warsaw 2007.

[12] Szwaja, S., Knock and Combustion Rate Interaction in Hydrogen Fuelled Combustion Engine, Journal of KONES Powertrain and Transport, Vol. 18, No. 3, pp. 431-438, Warsaw 2011.

[13] Grab-Rogaliński, K., Szwaja, S., Hydrogen combustion in the supercharged engine, Journal of KONES Powertrain and Transport, Vol. 19, No. 3, pp. 149-156, Warsaw 2012.

[14] Szwaja, S., Cupiał, K., Grab-Rogaliński, K., Anomalies in combustion of hydrogen in a SI engine modified to work as a supercharged one, Journal of KONES Powertrain and Transport, Vol. 19, No. 3, pp. 437-442, Warsaw 2012.

[15] http://superauto24.se.pl

[16] Jach, A., Rudy, W., Dąbkowski, A., Teodorczyk, A., Numerical and experimental investigations on self-ignition process of hydrogen gas release, Journal of KONES Powertrain and Transport, Vol. 20, No. 3, pp. 185-192, 2013.

[17] http://www.nrel.gov/docs/fy04osti/36705.pdf

[18] http://www.cenapradu.republika.pl/

[19] http://gigawat.info

[20] http://www.coal2nuclear.com/Hydrogen\%20\%20First\%20Industrial\%20Scale\%20Power\%20 Plant.pdf

[21] http://cng.auto.pl/pl/component/content/article/48-polska/376-cena-cng-na-stacjach-wpolsce.html

[22] http://www1.eere.energy.gov/hydrogenandfuelcells/mypp/pdfs/production.pdf

[23] Szwaja, S., Naber, J. D., Dual nature of hydrogen combustion knock, Int J of Hydrogen Energy, 38, pp. 12489-12496, 2013. 